\title{
EVALUATION OF HEMOSTATIC PARAMETERS AND SERUM AMYLOID (A) IN HORSES WITH ABDOMINAL PAIN
}

\author{
NASR-ELDIN M. AREF ${ }^{1}$; AHMAD A. AAMER ${ }^{1}$; SHIMAA H.M. HASSANIN² AND \\ MOHAMMED E. RADWAN ${ }^{2}$ \\ ${ }^{1}$ Department of Animal Medicine, Faculty of Veterinary Medicine, Assiut University, Assiut 71526- Egypt \\ ${ }^{2}$ Animal Health Research Institute, Assiut-Egypt
}

Received: 20 December 2017; Accepted: 22 January 2018

\begin{abstract}
The objective of the present study was to investigate the coagulation disorders and acute phase protein (serum amyloid A) in horses with abdominal pain. A total of 80 native breed horses of both sexes were examined. Based on the history, physical and laboratory investigations, the examined horses were classified into two groups: group $1(\mathrm{n}=30)$ : Healthy served as a control, and group $2(\mathrm{n}=50)$ exhibited clinical signs of abdominal pain. Animals in group 2 were retrospectively subdivided into 3 subgroups: Diarrhea $(n=10)$, Impaction $(n=18)$ and Spasm $(n=22)$. The obtained results revealed that all horses with abdominal pain showed restlessness, sweating, lip curling, flank watching, pawing, rolling, and an increase in the heart and respiratory rate as well as capillary refilling time (CRT). On abdominal auscultation, horses with spasm and diarrhea had intestinal hypermotility while there was reduction in intestinal sounds in horses with impaction. Hematological examination showed subtle changes in hemogram and leukogram in diseased group. Hemostatic profile showed significant decrease $(\mathrm{p}<0.05)$ in platelet count $\left(\mathrm{PLT} \times 10^{4} / \mu \mathrm{l}\right)$ in diarrheic and impacted groups $(14.3 \pm 1.35$ and $14.9 \pm 0.78$, respectively) and significant increase $(\mathrm{p}<0.05)$ in prothrombin time $(\mathrm{PT} / \mathrm{sec})$ in spasmodic group $(14.00 \pm 0.75)$ and marginally increase in diarrheic and impacted groups $(12.40 \pm 0.57$ and $12.70 \pm 1.37$, respectively). Additionally, activated partial thromboplastin time (APTT/sec) was significant increased $(\mathrm{p}<0.05)$ in spasmodic group $(53.79 \pm 2.44)$ and marginally increased in diarrheic and impacted group $(48.3 \pm 5.75$ and $45.7 \pm 4.13$, respectively). Antithrombin III (AT III, mg/dl) was marginally decreased in horses suffering from diarrhea, impaction and spasm $(29.0 \pm 3.42,29.7 \pm 3.19$ and $29.6 \pm 2.73$, respectively). Level of serum amyloid A $(\mu \mathrm{g} / \mathrm{ml})$ showed significant increase $(\mathrm{p}<0.05)$ in diarrheic and spasmodic groups $(2.03 \pm 0.50$ and $1.6 \pm 0.16$, respectively), while marginally increase in impacted group $(1.32 \pm 0.09)$.
\end{abstract}

In conclusion, abdominal pain in horses induces changes in the coagulation system and acute phase protein (serum amyloid A). Serum amyloid A is a sensitive biomarker for abdominal pain in horses and could be used as diagnostic biomarker for equine colic.

Key words: equine, colic, hemostatis, serum amyloid A

\section{INTRODUCTION}

Equine colic is considered as the most universally experienced health problem and remained as the common cause of death in horses (Snyder and Spier, 1992).Horses with colic are generally exhibited signs of abdominal pain (Abutarbush et al., 2005) including restlessness, kicking, rolling, sweating, getting up and lying down, flank watching and pawing (Alsaad and Nori, 2010). Horses are susceptible to a variety of gastrointestinal incidents, manifesting themselves asepisodes of abdominal pain or colic. Anatomical and epidemiological studies have identified several risk factors such as long gastrointestinal tract with marked variations in its diameter (White et al., 2008), improper feeding

Corresponding author: Dr. Nasr-Eldin M. Aref

E-mail address: nasreldeen.aref@vet.au.edu.eg

Present address: Department of Animal Medicine, Faculty of

Veterinary Medicine, Assiut University, Assiut 71526, Egypt. strategy, changes in management practices and lack of water access (Kaneene et al., 1997; Jennings et al., 2014).

Hemostatis is a complex process with positive and negative regulators for formation or degradation of fibrin (Prasse et al., 1993). Imbalanced regulation may lead to hyper-coagulation (thrombosis), hypocoagulation (hemorrhage) or paradoxically to both of them (Byars, 1987; Collatos et al., 1995; Petterson et al., 1995). Hemostatic dysfunction is reported in colic (Monreal et al., 2000). Systemic activation of the coagulation system associated with inflammation and/or endotoxemia may result in thrombocytopenia from platelet activation and consumption (Walton, 2012). Identification of platelet activation may allow early therapeutic intervention for prothrombotic status in colic patients with an inflammatory etiology (Hackner, 2011). Hemostatic alterations are expected outcomes in horses diagnosed with acute abdomen 
and probably associated with high rates of morbidity and mortality in those animals.

Recently, studies on acute phase proteins have drawn the attention of equine veterinary community for its ability to indicate inflammation (Anhold et al., 2014). Serum amyloid A (SAA) has been identified as a major acute phase protein in humans and several veterinary species including horses (Hulte'n and Demmers, 2002 and Jacobsen et al. (2004). It is produced in the liver as a part of body defense in response to stimuli including trauma, pain stress, infection, neoplasia and inflammation (Pihl et al., 2013).

We propose that levels of hemostatic parameters and SAA can be useful as a diagnostic aid in equine colic. Therefore, the present study aimed to evaluate the serum amyloid A (SAA) as a major acute phase protein and hemostatic profile in terms of platelet count (PLT), prothrombin time(PT), activated partial thromboplastin time (APTT) and antithrombin III (AT III) in horses with abdominal pain.

\section{MATERIALS ANDMETHODS}

Animals: The study population included those equines admitted at the Veterinary Teaching Hospital (VTH), Faculty of Veterinary Medicine, Assuit University, Brooks Hospital and Animal Care Egypt (ACE) at Luxor Governorate. Total number of 80 animals of both sexes and different ages (2 -7 years) were included in the present study. These animals were classified into two main groups: Healthy one (n $=30$ ) served as a control and diseased one with abdominal pain $(n=50)$. Diseased animals were retrospectively subdivided into 3 subgroups: diarrheic $(n=10)$, impaction $(n=18)$ and $\operatorname{spasm}(n=22)$.

Samples: Ten ml blood samples were collected from all animals by means of jugular vein puncture using $18 \mathrm{G}$ needle. Blood samples were distributed and used as following: $2.5 \mathrm{ml}$ of blood mixed with EDTA for complete blood count (CBC), $5 \mathrm{ml}$ of blood mixed with $3.8 \%$ sodium citrate (1 part citrate: 9 parts blood) used for collection of citrated plasma for determination of hemostatic parameters. $2.5 \mathrm{ml}$ blood without anticoagulant for serum collection for determination of serum amyloid A (SAA).

Reagent and kits: Thromborel®S, Pathromtin $® S L$ and Berichrom*antithrombin III reagents were obtained from Siemens Healthcare Diagnostics Product (U.S.A) and used for determination of Prothrombin Time (PT), Activated Partial Thromboplastin Time (APTT) and functionally active Anti -Thrombin III (ATIII). ELISA kit for determination of serum amyloid $\mathrm{A}$ in horses was obtained from WKEA Med (China).

Adopted Methods

History and clinical examination: Animal's data and general examination including age, sex, duration of clinical signs, body temperature $\left({ }^{\circ} \mathrm{C}\right)$, respiratory rate ( $\mathrm{RC} / \mathrm{min}$ ), heart rate (beats/min) and CRT (sec) were recorded. Physical examination was conducted according to Smith (2002).

Complete blood count (CBC) evaluation: Samples were analyzed directly after collection for CBC including total red blood cells (TRBCs $\left.\times 10^{6} / \mu \mathrm{l}\right)$ ), hemoglobin $(\mathrm{Hb}, \mathrm{g} / \mathrm{l})$, packed cell volume $(\mathrm{PCV} \%)$, mean corpuscular volume (MCV/fl), mean corpuscular hemoglobin $(\mathrm{MCH} / \mathrm{pg})$ and mean corpuscular hemoglobin concentration $(\mathrm{MCHC}, \mathrm{g} / \mathrm{dl})$, total white blood cells $\left(\mathrm{TWBCs} \times 10^{3} / \mu \mathrm{l}\right)$ and differential leukocytic count. Platelet enumeration $\left(\mathrm{PLT} \times 10^{4} / \mu \mathrm{l}\right)$ was also recorded on CBC report.

Determination of hemostatic parameters: Hemostatic assays were determined on citrated blood samples. The following parameters were determined.

Prothrombin time (PT/sec) was determined according to Poller, (1998) and CLSI (2008). Plasma PT level was determined on an automated analyzer using lyophilized human placental calcium thromboplastin (Thromborel®s reagent)as an activator of the extrinsic pathway of coagulation. The coagulation process is initiated by incubation of plasma with an optimal amount of thromboplastin and calcium for activation of extrinsic coagulation factors. The time to formation of fibrin clot is then measured. Briefly, $200 \mu \mathrm{l}$ of Thromborel ${ }^{\circledR}$ s reagent was added to $100 \mu$ of citrated plasma and the coagulation time was determined using Thrombostat coagulometer (German manufacturer Behnk Elektronik)

Activated partial thromboplastin time (APTT/sec) is a screening test used to assess the intrinsic pathway of coagulation and was determined according to Thomson and Poller (1985). Briefly, $100 \mu \mathrm{l}$ of citrated plasma sample was incubated with $100 \mu \mathrm{l}$ of Pathromtin SL (phospholipids comprising partial thromboplastin and a surface activator silicon dioxide particles) to activate the intrinsic coagulation system. The addition of calcium ions $(100 \mu \mathrm{l}$ of calcium chloride solution) triggers the coagulation process. The time to formation of fibrin clot is measured in second using Thrombostat coagulometer (German manufacturer Behnk Elektronik).

Antithrombin activity (ATIII, mg/dl): Antithrombin activity (AT III), physiological inhibitor of thrombin (Olson and Björk 1994), was determined with an automated analyzer using a chromogenic substrate test kit, Berichrom ${ }^{\circledR}$ Antithrombin III, at 37 ${ }^{\circ} \mathrm{C}$ according to Hathaway, (1991). The assay is based on the inhibition of thrombin by AT III and the residual thrombin content is determined kinetically using chromogenic substrate at absorbance $405 \mathrm{~nm}$. Briefly, plasma sample was diluted with isotonic saline at 1:40. Fifty $\mu \mathrm{L}$ of diluted plasma sample was added to $1000 \mu \mathrm{L}$ of thrombin reagent, thoroughly mixed and incubated for 3 minutes, then $100 \mu \mathrm{L}$ of 
substrate reagent (Berichrom®antithrombin III) was added and mixed. The amount of color released decreases linearly with the amount of antithrombin III present in the test sample. The absorbance was measured spectrophotometrically at $405 \mathrm{~nm}$.

Determination of serum amyloid A $(\mu \mathrm{g} / \mathrm{ml})$ : SAA was determined according to Jacobsen and Anderson, (2007). ELISA test allows for in vitro quantitative determination of horse SAA concentrations in serum, plasma and other biological fluid. The kit assays SAA level in the tested sample using purified horse SAA antibody coated-microtiter plate wells. Briefly, 100 $\mu \mathrm{L}$ of serum sample was added to each well, mixed and incubated for $30 \mathrm{~min}$ at $37^{\circ} \mathrm{C}$, washed and blotted dry 3 times. $100 \mu \mathrm{L}$ of horse reddish peroxidase antibody conjugate reagent was added to each well, incubated for $30 \mathrm{~min}$ at $37^{\circ} \mathrm{C}$, washed and blotted dry 3 times. $100 \mu \mathrm{L}$ of substrate was added, and microtiter plate was incubated for $15 \mathrm{~min}$ at $37^{\circ} \mathrm{C}$, substrate became blue color. The reaction was stopped using $100 \mu \mathrm{L}$ sulphuric acid solution to each well. The optical density (OD) of each well was determined within 15 min by microtiter ELISA reader (Stat Fax 2100, Awareness, USA).

Statistical analysis: The obtained data were statistically analyzed using statistical software (GraphpadPrism 5). The mean value \pm standard error of the mean (SE) was calculated. The significance of variations between control and diseased group was determined using T-test followed by Tukey’s test.

\section{RESULTS}

History and clinical signs: Diseased horses were submitted with one or more of the following history: Eating large amount of grains, green fodders and rough dry fodder then stop eating, no defecation and/or diarrhea, anorexia and lying down. Initial assessment of submitted cases showed sign of pain (Figure 1a) including pawing, anxiety, and rolling on the ground. Submitted cases were classified according to etiology of abdominal pain into diarrhea $(n=10)$, impaction $(n=18)$ and spasm $(n=22)$. The mean values

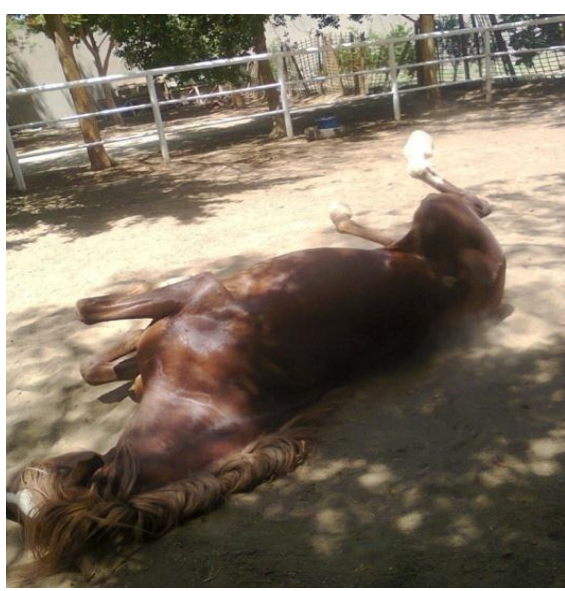

Figure 1a: Four years old- mare suffered from abdominal pain
$( \pm \mathrm{SE})$ of body temperature $\left({ }^{\circ} \mathrm{C}\right)$, respiratory rate ( $\mathrm{RC} / \mathrm{min})$, heart rate (beats/min) and CRT $(\mathrm{sec})$ in horse with diarrhea, impaction and spasm were presented in Table 1. Auscultation of the four quadrates of abdomen revealed loud intestinal sounds in spasm while there was marked reduction in the intestinal sounds in case of impaction with slight abdominal distention (Figure 1b). Rectal examination revealed no obvious abnormalities in spasm while there was hard material at the ventral colon in impaction.

Laboratory findings: Hematological analysis in healthy and diseased horses revealed marginally increase in different groups of abdominal pain, but not statistically difference (Table 2) and marginally decrease in TWBCs in colicky horses suffered from diarrhea, impaction and spasm with no variation in differential leukocytic count.

Results of hemostatic parameters in healthy and diseased animals were presented in Table 3 \& Figure 2a-d.Platelet count (PLT) was significant decreased $(p<0.05)$ in diarrheic and impacted groups while no statistically differences in spasmodic group (Figure 2a). Prothrombin time (PT) was significant increased $(\mathrm{p}<0.05)$ in spasmodic colic and marginally increased in impacted and diarrheic groups (Figure 2b). Additionally, activated partial thromboplastin time (APTT) was significant increased $(\mathrm{p}<0.01)$ in spasmodic group and marginally increased in impacted and diarrheic groups (Figure 2c). Determination of ATIII revealed marginally decrease in diarrheic, impacted and spasmodic groups (Figure 2d). SAA concentration in tested samples was determined by comparing the OD of the sample to the standard curve. Standard curve was prepared using various concentrations $(15 \mu \mathrm{g} / \mathrm{ml}, 10 \mu \mathrm{g} / \mathrm{ml}, 5 \mu \mathrm{g} / \mathrm{ml}$, $2.5 \mu \mathrm{g} / \mathrm{ml}, 1.25 \mu \mathrm{g} / \mathrm{ml}$ ) of SAA standard (Figure 3a). Results of serum amyloid A (SAA) in healthy and diseased horses were shown in Figure $3 \mathrm{~b}$. There were significant increased $(\mathrm{p}<0.05)$ in SAA in diarrheic and spasmodic groups, while marginally increased in impacted group.

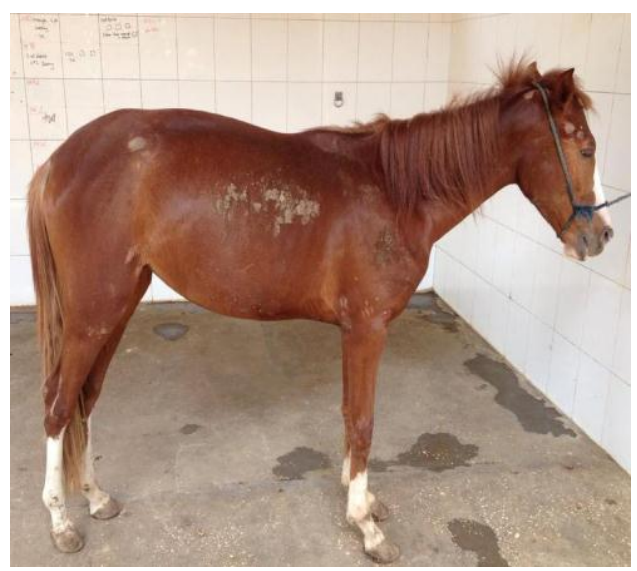

Figure 1b: Four years old- mare showed abdominal distention 


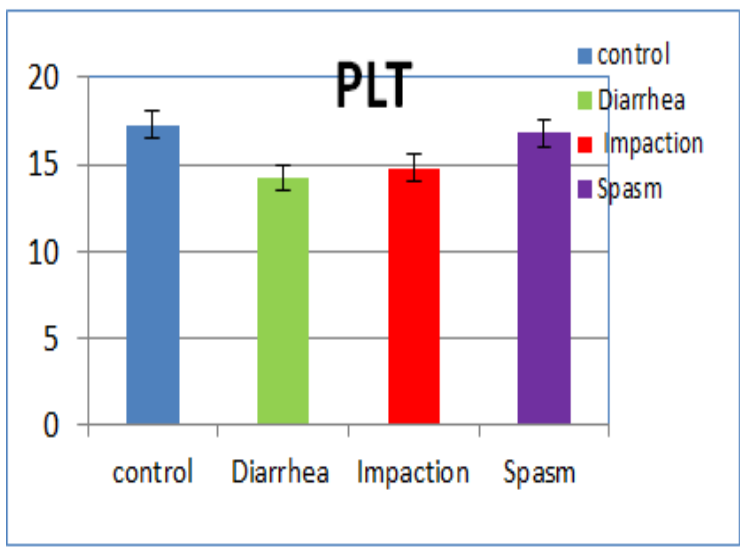

Figure 2a. Blood platelet count (PLTx $\left.10^{4} / \mu \mathrm{l}\right)$ in different groups of horses with abdominal pain

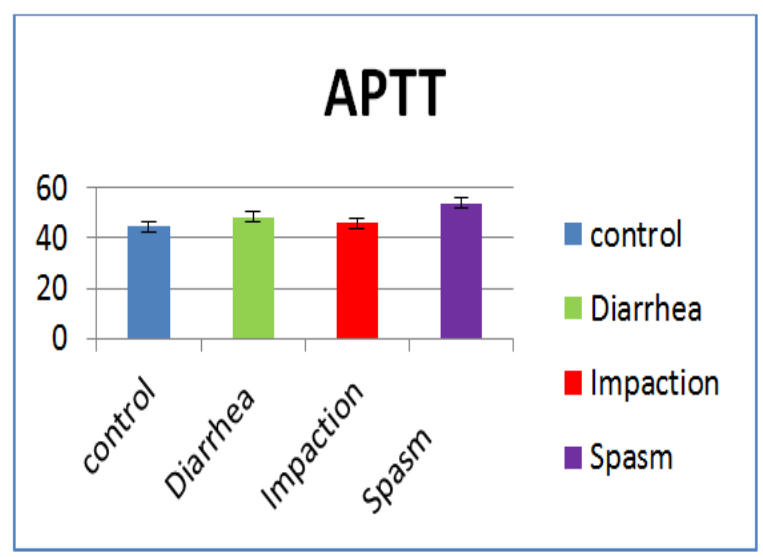

Figure 2.c. Activated partial thromboplastin time (APTT/sec) of different groups of horses with abdominal pain

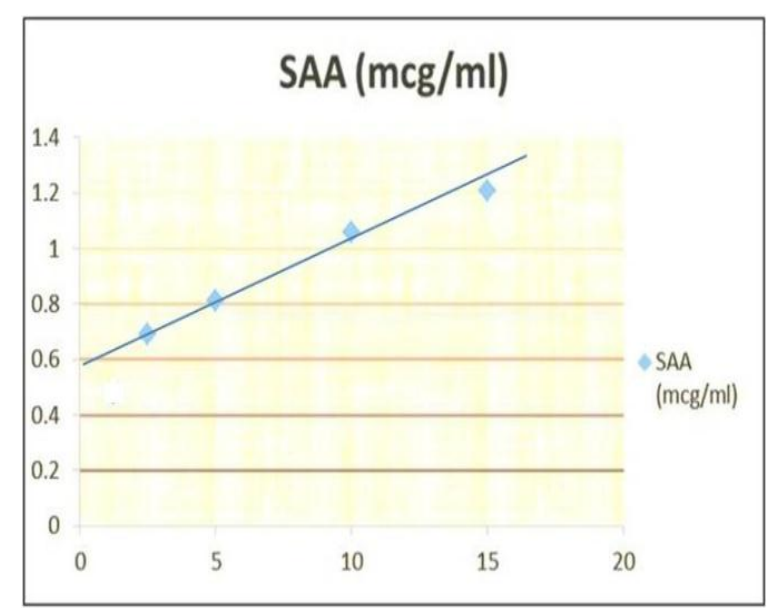

Figure 3a. Standard curve of serum amyloid A $(\mathrm{SAA}, \mu \mathrm{g} / \mathrm{ml})$ at various concentrations

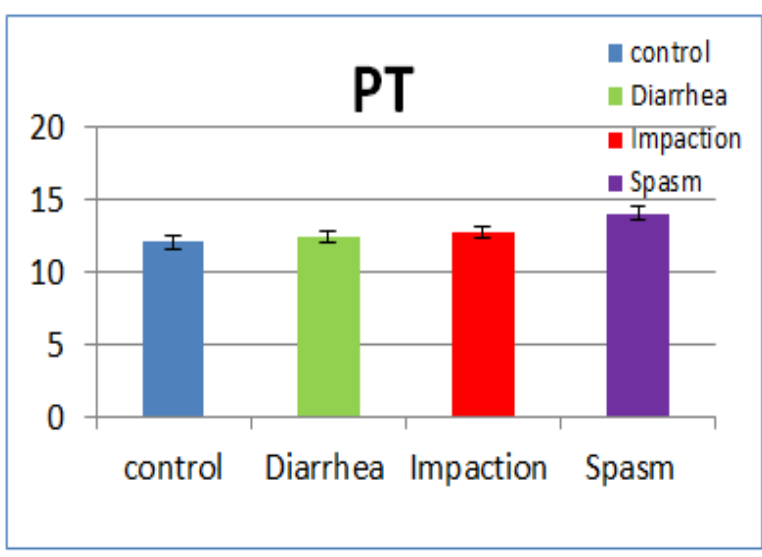

Figure 2.b. Prothrombine Time (PT/sec) in different groups of abdominal pain

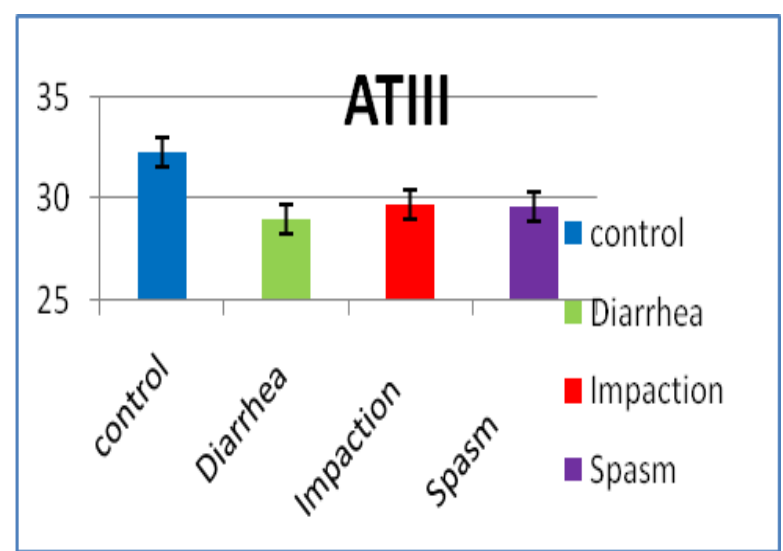

Figure 2.d. Anti -Thrombin III (AT III, mg/dl) of different groups of horses with abdominal pain

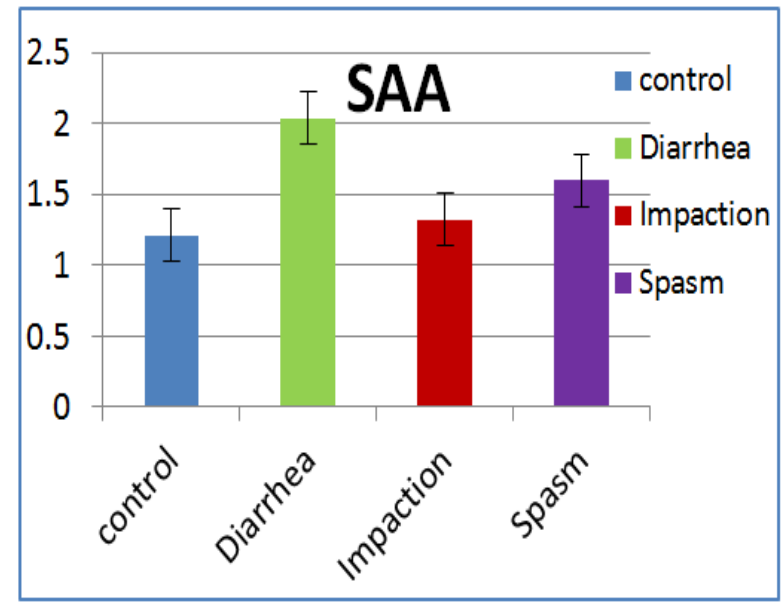

Figure 3.b. Serum amyloid A (SAA, $\mu \mathrm{g} / \mathrm{ml})$ level in different groups of horses with abdominal pain 
Table 1: Mean values $( \pm \mathrm{SE})$ of body temperature, respiratory rate, heart rate and CRT in horses with diarrhea, impaction and spasm

\begin{tabular}{lcccc}
\hline Parameter & $\begin{array}{c}\text { Control } \\
(\mathbf{n = 3 0})\end{array}$ & $\begin{array}{c}\text { Abdominal Pain } \\
\text { with Diarrhea } \\
(\mathbf{n = 1 0})\end{array}$ & $\begin{array}{c}\text { Abdominal Pain } \\
\text { with Impaction } \\
(\mathbf{n = 1 8})\end{array}$ & $\begin{array}{c}\text { Abdominal Pain } \\
\text { with Spasm } \\
(\mathbf{n = 2 2})\end{array}$ \\
\hline Temperature $\left(\mathbf{(}^{\mathbf{0}} \mathbf{C}\right)$ & $37.5 \pm 0.10$ & $38.5 \pm 0.28$ & $37.7 \pm 0.18$ & $38.3 \pm 0.28$ \\
\hline Respiration rate $(\mathbf{c y c l e} / \mathrm{min})$ & $17.0 \pm 0.58$ & $18.3 \pm 1.81$ & $17.1 \pm 0.66$ & $20.2 \pm 0.69$ \\
\hline Heart rate $($ beat/min) & $40.56 \pm 0.51$ & $41.3 \pm 1.48$ & $42.7 \pm 1.79$ & $48.2 \pm 1.95$ \\
\hline Capillary refilling time (CRT/sec) & $1.7 \pm 0.09$ & $2.0 \pm 0.33$ & $3.2 \pm 0.37$ & $2.4 \pm 0.26$ \\
\hline
\end{tabular}

Table 2: Mean values ( \pm SE) of hematological parameters of different groups of abdominal pain

\begin{tabular}{|c|c|c|c|c|}
\hline Parameters & $\begin{array}{c}\text { Control } \\
(\mathbf{n}=\mathbf{3 0})\end{array}$ & $\begin{array}{l}\text { Abdominal pain } \\
\text { associated with } \\
\text { diarrhea }(n=10)\end{array}$ & $\begin{array}{l}\text { Abdominal pain } \\
\text { associated with } \\
\text { impaction }(n=18)\end{array}$ & $\begin{array}{l}\text { Abdominal pain } \\
\text { associated with } \\
\operatorname{Spasm}(n=22)\end{array}$ \\
\hline RBCs $\left(\times 10^{6} / \mu \mathrm{l}\right)$ & $6.87 \pm 0.24$ & $6.78 \pm 0.51$ & $6.59 \pm 0.319$ & $7.02 \pm 0.39$ \\
\hline HB (g/dl) & $11.59 \pm 0.34$ & $11.27 \pm 0.61$ & $11.69 \pm 0.571$ & $12.04 \pm 0.59$ \\
\hline $\operatorname{PCV}(\%)$ & $31.0 \pm 0.80$ & $34.49 \pm 1.45$ & $32.28 \pm 1.41$ & $34.17 \pm 1.63$ \\
\hline $\operatorname{MCV}(\mathbf{f l})$ & $48.10 \pm 4.91$ & $46.91 \pm 1.94$ & $46.06 \pm 1.37$ & $48.29 \pm 1.36$ \\
\hline MCH (pg) & $17.13 \pm 2.10$ & $16.94 \pm 0.68$ & $17.71 \pm 0.518$ & $17.49 \pm 0.63$ \\
\hline MCHC (g/dl) & $35.69 \pm 3.55$ & $36.23 \pm 1.36$ & $37.41 \pm 0.97$ & $36.24 \pm 0.93$ \\
\hline PLT $\left(\times 10^{4} / \mu \mathrm{l}\right)$ & $17.3 \pm 0.78^{\mathrm{a}}$ & $14.3 \pm 1.35^{\mathrm{b}}$ & $14.9 \pm 0.78^{\mathrm{b}}$ & $16.85 \pm 0.55^{\mathrm{a}}$ \\
\hline TWBCs $\left(\times 10^{3} / \mu \mathrm{l}\right)$ & $12.88 \pm 0.63$ & $11.08 \pm 1.38$ & $10.66 \pm 1.05$ & $11.86 \pm 1.19$ \\
\hline Neutrophil $\left(10^{3} / \mu \mathrm{l}\right)$ & $7.72 \pm 0.65$ & $6.84 \pm 1.16$ & $6.71 \pm 1.17$ & $6.99 \pm 0.92$ \\
\hline Lymphocytes $\left(10^{3} / \mu \mathrm{l}\right)$ & $3.79 \pm 0.23$ & $3.08 \pm 0.32$ & $3.59 \pm 0.39$ & $3.48 \pm 0.45$ \\
\hline Monocytes $\left(10^{3} / \mu \mathrm{I}\right)$ & $0.75 \pm 0.06$ & $0.9 \pm 0.28$ & $0.67 \pm 0.115$ & $0.65 \pm 0.09$ \\
\hline Eosinophil $\left(10^{3} / \mu \mathrm{l}\right)$ & $0.04 \pm 0.016$ & $0.02 \pm 0.015$ & $0.03 \pm 0.014$ & $0.04 \pm 0.029$ \\
\hline Basophil $\left(10^{3} / \mu \mathrm{l}\right)$ & $0.35 \pm 0.055$ & $0.21 \pm 0.072$ & $0.23 \pm 0.054$ & $0.43 \pm 0.12$ \\
\hline
\end{tabular}

For each parameter, different letters indicate significant differences when compared with the control group.

Table 3: Mean values ( \pm SE) of coagulation parameters in different groups of abdominal pain

\begin{tabular}{|c|c|c|c|c|}
\hline Parameter & $\begin{array}{c}\text { Control } \\
(n=30)\end{array}$ & $\begin{array}{l}\text { Abdominal pain } \\
\text { associated with } \\
\text { diarrhea }(n=10)\end{array}$ & $\begin{array}{l}\text { Abdominal pain } \\
\text { associated with } \\
\text { impaction }(n=18)\end{array}$ & $\begin{array}{l}\text { Abdominal pain } \\
\text { associated with } \\
\text { spasm }(n=22) \\
\end{array}$ \\
\hline PLT $\left(\times 10^{4} / \mu \mathrm{l}\right)$ & $17.3 \pm 0.78^{\mathrm{a}}$ & $14.3 \pm 1.35^{\mathrm{b}}$ & $14.9 \pm 0.78^{\mathrm{b}}$ & $16.85 \pm 0.55^{\mathrm{a}}$ \\
\hline PT (sec) & $11.9 \pm 0.29^{\mathrm{a}}$ & $12.4 \pm 0.57^{\mathrm{a}}$ & $12.7 \pm 1.37^{\mathrm{a}}$ & $14.0 \pm 0.75^{\mathrm{b}}$ \\
\hline APTT (sec) & $44.32 \pm 2.26^{\mathrm{a}}$ & $48.3 \pm 5.75^{\mathrm{a}}$ & $45.7 \pm 4.13^{\mathrm{a}}$ & $53.79 \pm 2.44^{\mathrm{b}}$ \\
\hline AT III (mg/dl) & $32.26 \pm 1.84$ & $29.0 \pm 3.42$ & $29.7 \pm 3.19$ & $29.6 \pm 2.73$ \\
\hline
\end{tabular}

For each parameter, different letters indicate significant differences when compared with the control group.

\section{DISCUSSION}

Equine colic remained as the most common cause of death in horses and a major concern for all horse owners. During clinical examination, horses expressed signs of abdominal pain, kicking at the abdomen, lying down, rolling, pawing, sweating, stretching and reduced fecal output were recorded. These findings were in an agreement with those reported by Pratt et al. (2003); Alsaad and Nori, (2010) and Scantlebury et al. (2011). Abdominal pain could be attributed to severe intestinal contractions, inflammation, abdominal distension with over stretching of the intestine making severe stimulation of nociceptors (Reeves et al., 1989 and Radostits et al., 2007).

Horses with abdominal pain due to diarrhea, impaction and spasm showed increase in the heart rate $(41.3 \pm 1.48,42.7 \pm 1.79$ and $48.2 \pm 1.95$ beats/min, respectively), respiratory rate $(18.3 \pm 1.81,17.1 \pm 0.66$ and $20.2 \pm 0.69 \mathrm{RC} / \mathrm{min}$, respectively) and in capillary refilling time $(2.0 \pm 0.33,3.2 \pm 0.37$ and $2.4 \pm 0.26$ CRT/sec, respectively). Abdominal auscultation revealed reduction in intestinal motility in case of impaction, while diarrheic and spasmodic groups showed audible sounds. These findings agreed with those reported by Thoefner et al. (2001); Hillyer et al. (2008), Bryan et al. (2009), Sutton et al. (2009); 
Alsaad and Nori (2010) and Ibrahim, (2014). The increasing in heart rate, respiratory rate and CRT in affected horses could be associated with pain and poor peripheral perfusion.

Screening of the hematological data revealed no significant changes in the hemogram, however packed cell volume (PCV \%) showed marginally increased, but not statistically difference. Slight increase in PCV could be attributed to some degree of dehydration and malabsorption which are common features in intestinal disturbances (Ayazet al., 1999; Radostits et al., 2007 and Alsaad and Nori, 2010). While the short course of abdominal pain associated with spasm, diarrhea and impaction did not have major changes on the hemogram values; there was marginally decrease in TWBCs. This could be related to stress and abdominal discomfort (Lassen and Swardson, 1995; Moore and Palmer 2001; Radostits et al., 2007).

The minimum laboratory data needed to evaluate hemostasis in equines are PLT, PT, APTT and AT III (Morris, 1990). Brooks (2008) reported that tests used to evaluate the hemostatic function can be classified as tests of primary (PLT count) and secondary hemostasis (PT, APTT and AT III). Evaluation of these indices are the most useful and practical because they assess the intrinsic and extrinsic pathway of coagulation process (Roberts et al., 2006). In the current study, platelet count $\left(\mathrm{PLT} \times 10^{4} / \mu \mathrm{l}\right)$ revealed significant decrease $(\mathrm{p}<0.05)$ in diarrhea and impaction (14.3 \pm 1.35 and $14.9 \pm 0.78$, respectively), and no statistical differences in spasm (16.85 \pm 0.55$)$. Thrombocytopenia could be attributed to platelet activation, consumption and depletion due to the release of endogenous mediators such as platelet activating factor in inflammatory disorders (Imaz et al., 2002). Our results were in an agreement with Sandholm et al. (1995) and Monreal et al. (2000). Data of PT ( $\mathrm{sec}$ ) and APTT (sec) revealed significant increase in spasmodic colic (PT 14.0 0.75 and APTT $53.79 \pm 2.44$ ) and marginally increased in impaction and diarrheic groups. These findings were in an agreement with Michelle and Moore (1991). Authors reported prolongation in PT and APTT were considered the most frequently observed abnormality in horses with colic. This could be explained as a result of decreased coagulation factors that is related to consumption coagulopathy of coagulation factors (Barton et al., 1998 and Weiss and Rashid, 1998).

Antithrombin III (ATIII) is a regulator of thrombin and other procoagulant enzymes. It considered a major inhibitor of thrombin and other serine proteases of the coagulation system (Monreal et al., 2000). In our study, values of AT III $(\mathrm{mg} / \mathrm{dl})$ revealed marginally decrease in diarrheic, impacted and spasmodic groups $(29.0 \pm 3.42,29.7 \pm 3.19$ and 29.6 \pm 2.73 , respectively). These results consistent with those reported by other investigators (Morris, 1990;
Welch et al., 1992 and Monreal et al., 2000) which support the statement that decreased AT III activity is common in horses with gastrointestinal disorders. This result could be associated with depletion and consumption of procoagulant modulator ATIII in an acute consumptive coagulopathy (Darien et al., 1989).

Zbanyszek et al. (2004) reported that colic in horses often alters the coagulation system, which promoted by an increase in exposition of coagulation activators with a simultaneous decrease in coagulation inhibitors activity, mainly antithrombin III. Coagulopathy with decreased procoagulant and profibrinolytic factors is common in horses with gastrointestinal disease (Monreal et al., 2000, Dallap and Epstein, 2009 and Cesarini et al., 2010). These changes are consistent with activation and subsequent consumption of coagulation factors. Künzer (1988) stated that consumption coagulopathy occurred due to imbalance or disturbance of blood clotting system which leading to an increased turnover of coagulation factors and platelets. The author added that after a period of hypercoagulability, hemostasis changes into hypo-coagulability due to deficiency of coagulation factors and platelets in circulation.

In this regards, horses with gastrointestinal disorders such as diarrhea, impaction and severe intestinal contraction as in spasm could be associated with endotoxin production. Endotoxin and tissue thromboplastin released from damaged gastrointestinal tract may activate the extrinsic and intrinsic coagulation factors (Johnstone and Crane, 1986). The moderate thrombocytopenia and prolonged clotting times (PT and APTT) in horses were indicative of platelet/ clotting factor activation and consumption (Johnstone and Blackwell, 1984).

Moreover, horses with acute gastrointestinal disease induced an acute phase reaction with consecutive changes in the coagulation parameters mainly reflected by increased level of acute phase protein, serum amyloid A (Topper and Prasse, 1998 and Anhold et al., 2014). Serum amyloid A (SAA) has become increasingly recognized by equine veterinary community for its ability to indicate early inflammation and identified as a major acute phase protein in horses (Anhold et al., 2014 and El-Deeb et al., 2016). In the present study, levels of SAA $(\mu \mathrm{g} / \mathrm{ml})$ showed significant increase $(\mathrm{p}<0.05)$ in diarrheic and spasmodic groups $(2.035 \pm 0.50$ and $1.6 \pm 0.16$, respectively) and marginally increased in impacted group $(1.32 \pm 0.089)$. These results agreed with Nunokawa et al. (1993) and Vandenplas et al. (2005); Pihl et al. (2013) and Dondi et al. (2015). Pihl et al. (2013) stated that the concentration of SAA increased quickly in response to inflammation and tissue injury. Moreover, the authors confirmed increasing in SAA as a response happened in animals with conflicts in hemostasis and subsequent tissue injury. 


\section{CONCLUSION}

Abdominal pain in horses due to diarrhea, spasm and impaction induces changes in the coagulation system (coagulopathy) in terms of thrombocytopenia, prolonged PT, APTT and decreased AT III. Serum amyloid $\mathrm{A}$ is a sensitive biomarker for abdominal pain in horses and could be used as diagnostic biomarker for equine colic.

\section{REFERENCES}

Abutarbush, S.M.; Carmalt. J.L. and Shoemaker, R.W. (2005): Causes of gastrointestinal colic in horses in Western Canada. Canadian Veterinary Journal, 46: 800-805.

Alsaad, K.M. and Nori, A.A. (2010): Clinical, Haematological and biochemical studies of colic syndrome in draught horses in Mosul. Proceedings of the $14^{\text {th }}$ Scientific Conference Faculty of Veterinary Medicine Assuit University, Egypt, 169-189.

Anhold, H.; Condon, R.; Chan, D. and Amos, W. (2014): Comparison of elevated blood parameter values in a population of thoroughbred racehorses. Journal of Equine Veterinary Science, 34: 651-655.

Ayaz, M.M.; Pervaz, K.; Khan, S.M.; Khan, S.A. and Ashraf, M. (1999): Clinical and biochemical studies in equine colic. Pakistan Veterinary Journal, 19: 91-93.

Barton, M.H.; Morris, D.D.; Norton, N. and Prasse, K.W. (1998): Hemostatic and fibrinolytic indices in neonatal foals with presumed septicemia. Journal of Veterinary Internal Medicine, 12: 26-35.

Bryan, J.; David, F. and Duggan, V. (2009): Investigation of acute colic in the adult horse. Irish Veterinary Journal, 62: 541-547.

Brooks, M.B. (2008): Equine coagulopathies. Veterinary Clinics North America: Equine Practice, 24: 335-355.

Byars, TD. (1987): Disseminated intravascular coagulation. In: Robinson, N.E. Current Therapy in Equine Medicine. $2^{\text {nd }}$ Ed. W.B. Saunders Comp., Philadelphia, pp 306-309.

Cesarini, C.;Monreal, L. and Armengou, L. (2010): Association of admission plasma d-dimer concentration with diagnosis and outcome in horses with colic. Journal of Veterinary Internal Medicine, 24: 1490-1497.

Collatos, C.; Barton, M.H.; Prasse, K.W. and Moore J.N. (1995): Intravascular and peritoneal coagulation and fibrinolysis in horses with acute gastrointestinal tract diseases. Journal of American Veterinary Medicine, 207: 465-470.

CLSI, Clinical and Laboratory Standards Institute, (2008): Collection, transport, and processing of blood specimens for testing plasma based coagulation assay and molecular hemostasis assays. Approved Guideline $5^{\text {th }}$ Ed. CLSI, 940 West Vally Road, Suite 1400, Wayne, Pennsylvania, U.S.A.

Darien, B.; Potempa. J.; Moor, N. and Travis, J. (1989): Antithrombin activity (residual thrombin activity) in plasma from nonmedicated or heparinized horses. Veterinary Research Communications, 13: 31-46.

Dallap, B.L. and Epstein, K. (2009): Coagulopathy of the critically ill equine patient. Journal of Veterinary Emergency Critical Care, 19: 5365 .

Dondi, F.;Lukacs, R.M.; Gentilini, F.;Rinnovati, R.; Spadari, A. and Romagnoli, N.(2015): Serum amyloid A, haptoglobin, and ferritin in horses with colic: Association with common clinicpathological variables and short-term outcome. The Veterinary Journal, 205:50-55.

El-Deeb, W.M.; Shawaf, T.M. and Al-Wahaimed, A.S. (2016): The diagnostic accuracy of serum amyloid A and cardiac troponin I in Arabian horses with obstructive colic. Journal of Veterinary Science and Medical Diagnosis, $5: 2$.

Hackner, S.G. (2011): Bleeding disorders: Diagnostic Approach Simplified. Cornell University Veterinary Specialists, 1-15.

Hathaway, W.E. (1991): Clinical aspects of antithrombin III deficiency. Semin Hematol, 28: $19-23$.

Hillyer, M.H.; Smith, M.R.W. and Milligan, P.J.P. (2008): Gastric and small intestinal ileus as a cause of acute colic in post parturient mare. Equine Veterinary Journal, 40: 368-372.

Hulte'n, C. and Demmers, S. (2002): Serum amyloid A (SAA) as an aid in the management of infectious disease in the foal: comparison with total leukocyte count, neutrophil count and fibrinogen. Equine Veterinary Journal, 34: 693-698.

Ibrahim, H.M.M. (2014): Oxidative stress associated with spasmodic, flatulent, and impaction colic in draft horses Journal of Equine Veterinary Science, 34: 1205-1210.

Jacobsen, S. and Andersen, P.H. (2007): The acute phase protein serum amyloid A (SAA) as a marker of inflammation in horses. Scandinavian Journal of Immunology, 19: 3846.

Jacobsen, S.; Andersen, P.H.; Toelboell, T. and Heegaard, P.M.H. (2004): Dose dependency and individual variability of the lipopolysaccharide- induced bovine acute phase protein response. Journal of Dairy Science, 87: 3330-3339.

Jennings, K.; Curtis, L.; Burford, J. and Freeman, S. (2014): Prospective survey of veterinary practitioners' primary assessment of equine colic: Clinical features, diagnoses, and treatment of 120 cases of large colon 
impaction. BMC Veterinary Research, 10: 110.

Johnstone, I.B. and Blackwell, T.E. (1984): Disseminated intravascular coagulation in a horse with postpartum ulcerative colitis and laminitis. Canadian Veterinary Journal, 25: 195-198.

Johnstone, I. and Crane, S. (1986): Hemostatic abnormalities in equine colic. American Journal of Veterinary Medicine, 18: 356-358.

Imaz, Z.Y.;Sentork, S. andllynl, Y.(2002): Analysis of hemostasis in horses with colic. Journal of Veterinary Medicine, 57: 65-67.

Kaneene, J.B.; Miller, R.; Ross, W.A.; Gallagher, K.;Marteniuk, J. and Rook, J. (1997): Risk factors for colic in the Michigan (USA) equine population. Preventive Veterinary Medicine, 30: 23-36.

Künzer, W. (1988): Therapy of consumption coagulopathies. Monatsschr Kinderheilkd, 136: 788-94.

Lassen, E.D. and Swardson, C.J. (1995): Hematology and hemostasis in the horse: normal functions and common abnormalities. Veterinary Clinics North America: Equine Practice, 11: 351-389.

Michelle, M.H. and Moore, J.N. (1991): Whole blood re-calcification time in equine colic. Equine Veterinary Journal, 23: 303-308.

Monreal, L.; Angles, A.; Espada, Y.; Monesterio, J. and Monreal, M. (2000): Hypercoagulation and hypofibrinolysis in horses with colic and DIC. Equine Veterinary Journal Supplement, 32: $19-25$

Moore, M.C. and Palmer, N.G. (2001): Calculations for Veterinary Nurses. $1^{\text {st }}$ Ed. Blackwell Science, London.

Morris, D.D. (1990): Alterations in the clotting profile. In: Smith B.P. (Ed.): Large Animal Internal Medicine, $1^{\text {st }}$ Ed. C.V. Mosby Comp., Philadelphia, 1990: pp: 445-451.

Nunokawa, Y.; Fujinaga, T.; Taira, T.; Okumura, M.; Yamashita, K.; Tsunoda, N. and Hagio, M. (1993): Evaluation of serum amyloid A protein as an acute phase reactive protein in horses. Journal of Veterinary Medical Science, 55: 1011-1016.

Olson, ST. and Björk, I. (1994): Regulation of thrombin activity by antithrombin and heparin. Semin Thromb Hemost.; 20: 373- 409.

Peterson, J.L.; Couto, C.G. and Wellman, M.L. (1995): Hemostatic disorder in cats: A retrospective study and review of the literature. J. Vet. Int. Med. 9: 298-303.

Pihl, T.H.; Andersen, P.H.; Kjelgaard-Hansen, M.; Morck, N.B. and Jacobsen, S. (2013): Serum amyloid $\mathrm{A}$ and haptoglobin concentrations in serum and peritoneal fluid of healthy horses and horses with acute abdominal pain. Veterinary Clinical Pathology, 42: 177-183.

Poller, L. (1998): The Prothrombin time. $\mathrm{WHO} / \mathrm{LAB} / 98.3$.
Prasse, KW.; Topper, MJ.; Moore, J.N. and Welles, $E G$. (1993): Analysis of hemostasis in horses with colic. Journal American Veterinary Medical Association, 203: 685-693

Pratt, S.M.; Hassle, D.M.; Drake, C. and Snyder, J. (2003): Clinical characteristics of horses with gastrointestinal ruptures revealed during initial diagnostic evaluation: 149 cases (1990-2002). Journal Equine Sciences, 14: 55-58.

Radostits, O.M.; Gay, C.C.; Blood, D.C. and Hinchcliff, K.W. (2007): Veterinary Medicine: A Text Book of the Diseases of Cattle, Sheep, Pigs, Goats, and Horses. $10^{\text {th }}$ Ed. W.B. Saunders Co. pp: 215-229.

Reeves, M.J.; Curtis, C.R.; Salman, M.D. and Hilbert, B.J. (1989): Prognosis in equine colic patients using multivariable analysis. Canadian Journal of Veterinary Research, 53: 87-94.

Roberts, H.R.; Hoffman, M. and Monroe, D.M. (2006): A cell-based model of thrombin generation. Semin Thromb Hemost., 32: 3238.

Sandholm, M.; Vidovic, A.; Pouteran, R.A.; Sankari, S.; Nyholm, K. and Rita, H. (1995): D-Dimer improves the prognostic value of combined Clinical and laboratory data in equine gastrointestinal colic. Acta Veterinaria Scan., 36: 255-272.

Scantlebury, C.E.; Archer, D.C.; Proudman, C.J. and Pinchbeck, G.L. (2011): Recurrent colic in the horse: incidence and risk factors for recurrence in the general practice population. Equine Veterinary Journal, 43: 81-88.

Smith, B.P. (2002): Large Animal Internal Medicine. $3^{\text {rd }}$ Ed. St Louis: Mosby, pp: 108-111

Snyder, J.R. and Spier, R.J. (1992): Physical and laboratory evaluation of the horse with colic. In: Robinson, N. E. (Ed.) Current Therapy in Equine Medicine. $3^{\text {rd }}$ Ed. W.B. Saunders Company, Philadelphia; 1992:193.

Sutton, G.A.; Ertzman-Ginsbrg, R.; Steiman, A. and Milgram, J. (2009): Initial investigation of mortality rates and prognostic indicators in horses with colic in Israel: A retrospective study. Equine Veterinary Journal, 41: 482486.

Thomson, JM. and Poller, L. (1985): The activated partial thromboplastin time. In: Thomson J.M., $4^{\text {th }}$ Ed. Blood coagulation and haemostasis: A practical guide. Edinburgh: Churchill Livingstone London, New York, Melbourne, Tokyo, 301-39.

Thoefner, M.B.; Ersbollb, A.K.; Jensenc, A.L. and Hesselholt, M. (2001): Factor analysis of the interrelationships between clinical variables in horses with colic. Preventive Veterinary Medicine, 48: 201-214.

Topper, M.J. and Prasse, K.W. (1998): Analysis of coagulation proteins as acute-phase reactants in horses with colic. American Journal of Veterinary Research, 59:542-545. 
Vandenplas, M.L.; Moore, J.N.; Barton, M.H.; Roussel, A.J. and Cohen, N.D. (2005): Concentrations of serum amyloid $\mathrm{A}$ and lipopolysaccharide-binding protein in horses with colic. American Journal of Veterinary Research, 66: 1509-1516.

Walton, R.M. (2012): Clinical Laboratory Data. In: Southwood, L.L. Practical Guide to Equine Colic. John Wiley \& Sons, Inc., 2013, pp.7886.

White, N.A.; Moore, J.N. and Mair, T.S. (2008): The Equine acute abdomen, $2^{\text {nd }} E d$. Teton New Media, Jackson, pp. 368-371.
Weiss, D.J. and Rashid, J. (1998): The sepsiscoagulant axis: A review. Journal of Veterinary Internal Medicine, 12: 317-324.

Welch, R.D.; Watkins, J.P.; Taylor, T.S.; Cohen N.D. and Carter, G.K. (1992): Disseminated intravascular coagulation associated with colic in 23 horses (1984-1989). Journal of Veterinary Internal Medicine, 6: 29-35.

Zbanyszek, M.; Procajlo, A.; Stopyra, A.; Sobiech, P. and Rajski, K. (2004): The coagulation system in horses with colic. Polish Journal of Veterinary Sciences, 7:53-58.

\section{تقييم مؤشرات النزف ومصل الأميلويد (أ) في الخيول المصابة بآلام البطن \\ نصر اللين محمد عارف ، أحمد عبل الفتاح عامر ، شيداء محمد حسانين ، محد عزت رضوان \\ E-mail: nasreldeen.aref@vet.au.edu.eg Assiut University web-site: www.aun.edu.eg}

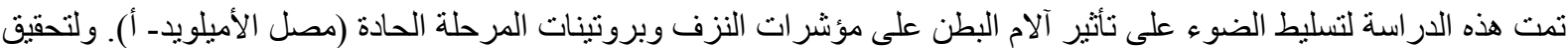

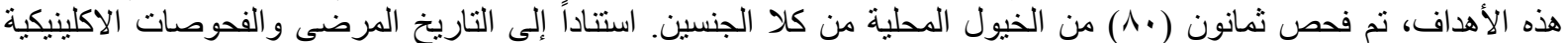

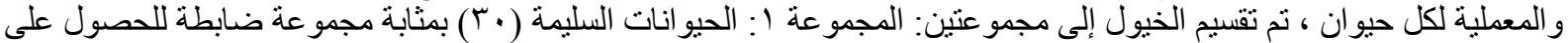

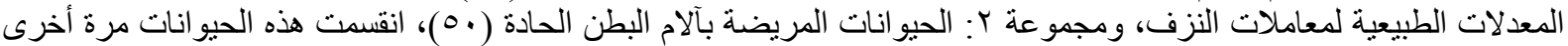

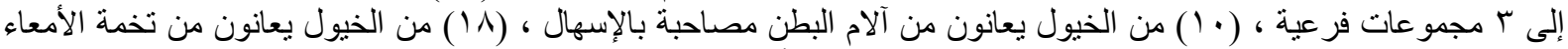

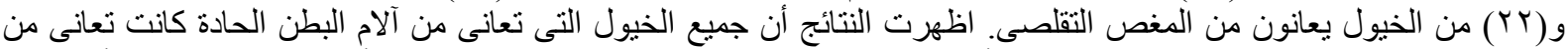

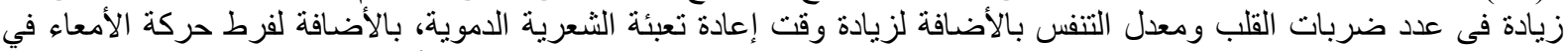

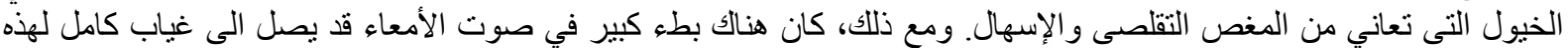

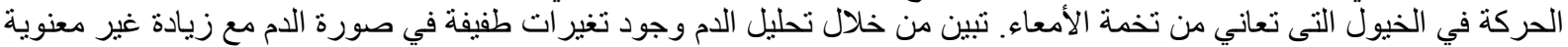

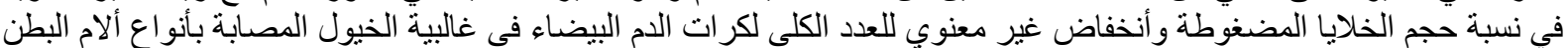

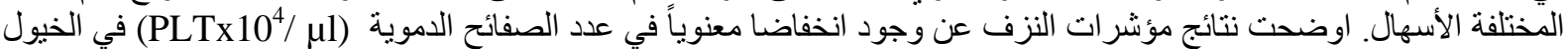

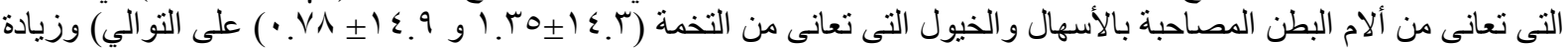

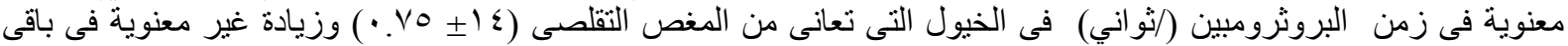

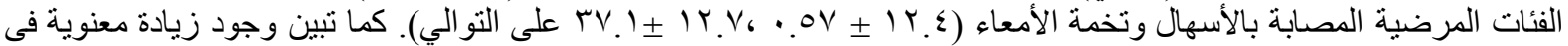

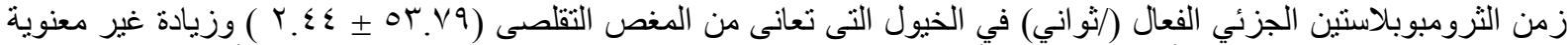

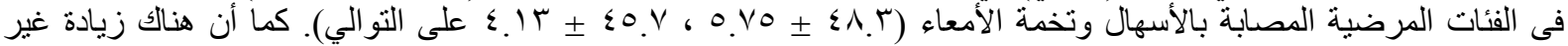

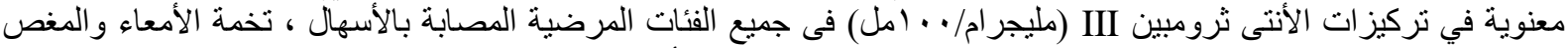

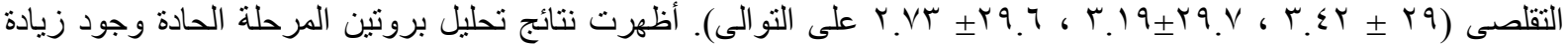

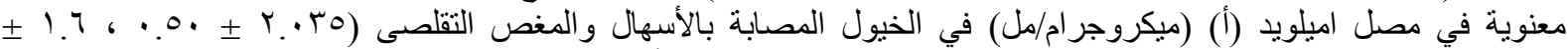

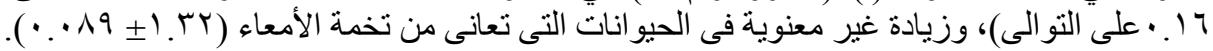

خلصت الدراسة إلى ظهور تغير ات فى مؤشرات النزف في الخيول التي تعاني من آلام البطن ولها تأثير معنوى على عدد الصفائح

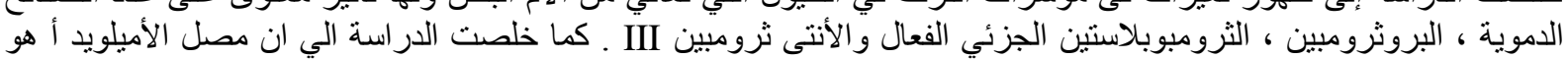

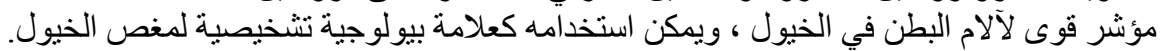

الكلمات الكاثفة: خيول ، مغص ، مؤشر ات النزف، مصل الأميلويد (أ) 